\title{
Prevalence and risk of spinal pain among physiotherapists in Poland
}

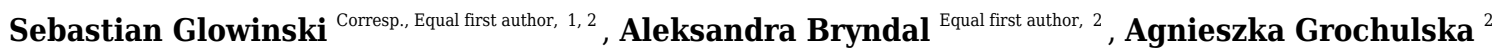 \\ 1 Department of Mechanical Engineering/Division of Mechatronics and Automatics, Technical University of Koszalin, Koszalin, zachodniopomorskie, Poland \\ 2 Institute of Health Sciences, Slupsk Pomeranian Academy, Slupsk, pomorskie, Poland \\ Corresponding Author: Sebastian Glowinski \\ Email address: sebastian.glowinski@tu.koszalin.pl
}

Background. The purpose of this study was to determine the prevalence, symptoms of, and risk factors for spinal pain in physiotherapists, as well as to analyse the correlation between these factors and the nature of the work, anthropometric features of the respondents, and the level of their physical activity.

Methods. The study was conducted among 240 physiotherapists (71 male and 169 female) with a mean age of 38.7 years. They were divided into three groups: physical therapy (37), kinesitherapy (158) and massage (45). Physiotherapists were evaluated with a specially designed questionnaire, the postural discomfort chart, the Neck Disability Index (NDI) questionnaire, and the Oswestry Disability Index (ODI) questionnaire.

Results. The analysis showed a $91.7 \%$ incidence of spinal pain in physiotherapists $(91.1 \%$ for kinesitherapy, $97.3 \%$ for physical therapy, and $88.9 \%$ for massage). The study revealed that $50.2 \%$ of physiotherapists indicated 1 to 5 pain episodes in their careers. Most respondents reported pain in the lumbosacral spine (82\%) and the cervical spine (67\%). Most respondents $(58.5 \%)$ scored the pain as moderate (VAS scale). Carrying (62.6\%) and torso bending (37.4\%) were indicated as the causes of pain.

Conclusions. Physiotherapists demonstrate a high prevalence of spinal pain. Physical activity reduces the frequency of pain episodes. 


\section{Prevalence and risk of spinal pain among physiotherapists in}

2 Poland

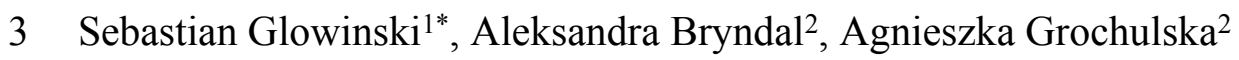

$4 \quad{ }^{1}$ Department of Mechanical Engineering/Division of Mechatronics and Automatics, Koszalin

5 University of Technology, Sniadeckich 2, 75453 Koszalin, zachodniopomorskie, Poland

62 Institute of Health Sciences, Slupsk Pomeranian Academy, Slupsk, pomorskie, Poland

$8{ }^{*}$ Corresponding Author:

9 Sebastian Glowinski

10 Email address: sebastian.glowinski@tu.koszalin.pl

11 Phone: +48943478395

12 ORCID: 0000-0003-3140-6313 


\section{Abstract}

14 Background. The purpose of this study was to determine the prevalence, symptoms of, and risk factors for spinal pain in physiotherapists, as well as to analyse the correlation between these factors and the nature of the work, anthropometric features of the respondents, and the level of their physical activity.

Methods. The study was conducted among 240 physiotherapists ( 71 male and 169 female) with a mean age of 38.7 years. They were divided into three groups: physical therapy (37), kinesitherapy (158) and massage (45). Physiotherapists were evaluated with a specially designed questionnaire, the postural discomfort chart, the Neck Disability Index (NDI) questionnaire, and the Oswestry Disability Index (ODI) questionnaire.

Results. The analysis showed a $91.7 \%$ incidence of spinal pain in physiotherapists $(91.1 \%$ for kinesitherapy, $97.3 \%$ for physical therapy, and $88.9 \%$ for massage). The study revealed that $50.2 \%$ of physiotherapists indicated 1 to 5 pain episodes in their careers. Most respondents reported pain in the lumbosacral spine (82\%) and the cervical spine (67\%). Most respondents (58.5\%) scored the pain as moderate (VAS scale). Carrying (62.6\%) and torso bending (37.4\%) were indicated as the causes of pain.

Conclusions. Physiotherapists demonstrate a high prevalence of spinal pain. Physical activity reduces the frequency of pain episodes.

\section{Introduction}

Neck pain (NP) and low back pain (LBP) are very common musculoskeletal disorders and leading causes of disability worldwide [1]. LBP is a complex therapeutic and diagnostic problem. Numerous epidemiological data show that $11 \%-84 \%$ of people experience, have experienced, or will experience pain in the lower spine at least once in their lives [2-4]. With a global prevalence of $9.4 \%$, LBP was ranked highest in the number of years lived with a disability and sixth in overall burden of disease [4]. The nature of occupational work related to musculoskeletal load promotes pain in the lower spine [5,6]. Pain very often occurs during lifting weights, frequently repeated bending over and rotations in the lower part of the spine, and maintaining one forced body position for a long time $[7,8]$. NP is also very common $[2,4]$, with a general prevalence in the general population of $0.4 \%-86.8 \%$. With a global prevalence of $4.9 \%$, NP ranks fourth in terms of general disability and $21 \mathrm{st}$ in terms of the overall burden of disease [4]. LBP is the most common musculoskeletal occupational disorder [8]. Worldwide, it is estimated that 37\% of LBP cases are work-related, and this problem causes 818,000 cases of disability per year [9]. As such, LBP is an economically important problem in developed countries. There is growing evidence that NP is associated with many occupational factors, including physical work requirements and workrelated psychosocial and organizational factors. In particular, studies have shown that abnormal postures, strenuous physical work, and repetitive and precise work are physical risk factors for NP. The occurrence of pain in the cervical part of the spine impacts the economic situation related to productivity, workers' compensation, as well as the reduction of the number of workers and their well-being throughout their lives [10, 11]. 
The causes of NP and LBP are multi-factorial, with age, sex, genetic makeup, obesity, environment and occupation playing significant roles [12, 13, 14]. Occupational factors associated with NP and LBP include the fast pace of work, repetitive movement patterns, insufficient recuperation time, heavy lifting, other strenuous manual work, non-neutral body postures, mechanical pressures, bending, twisting, vibrations and low temperature [9, 15].

In the profession of a physiotherapist, the main occupational risk factors affecting the locomotor system are dynamic physical load (physical effort, monotype of movements), static physical load (forced body position), and the possibility of falling. In general, the professional activities performed by PT are mainly physical work in combined planes. The way they are performed determines the forced body position. Movements within the same joints and forced positions are usually performed in a short time, but many times during the day, which leads to significant strain on the locomotor system. This results in a particularly high risk of injury or overload of spinal muscles, spinal ligaments or, ultimately, intervertebral discs [16, 17].

Physiotherapy (PT) comprises three main sections: kinesitherapy (movement therapy, therapeutic gymnastics), physical therapy (treatment involving physical stimulation, either natural or produced by devices), and massage. In each of these departments, the PT has a different nature of work, which may cause different overloads in the locomotor system. The main threats that are specific to a given specialty of physiotherapy include a mechanical overload of the musculoskeletal system (lifting patients, equipment, frequent repetition of the same movements); forced body position; bending and rotation of the torso with load; insufficient equipment for lifting and transferring patients; improper habits of lifting and carrying patients; unpredictable patient movements or falls. For the physical therapy specialty, it is routine and repetition of selected activities; the one-sided load on the musculoskeletal system; forced body position during the activity. For specialties, massage is a long-term leaning during the activity; mainly standing work; static physical workload with torso flexion and rotation; dynamic physical load - physical effort, monotype of movements [16,17].

Nowadays, the development of pathologies within the spine is strongly associated with the economic situation, and the working time of physiotherapists is significantly longer than the statutory limit, often reaching ten hours a day. For spinal pain to develop, many other factors must also occur. Among the most important ones are the anthropometric features of a given person, the level of his or her physical activity (since the physical nature of the work should not be identified with physical activity), genetic determinants, and history of traumas or diseases that may affect spinal function. The risk of disorders of spinal functions manifested by spinal pain is likely to be higher with the simultaneous impact of several factors mentioned above $[18,19]$. Taking into account the high frequency of spine problems among physiotherapists, the question arises whether the specificity of work in the selected specialization of physiotherapy is associated with a higher risk of these problems. So far, in the literature, in the assessment of factors contributing to the formation of back pain in the profession of a physiotherapist, no division into specialties has been applied due to the nature of the work in which a given physiotherapist works the most time (kinesitherapy, physical therapy, massage). We took this division in our manuscript. 
This study aims to analyse the incidence of spinal pain in Polish physiotherapists divided into specialties (kinesitherapy, physical therapy, massage), with consideration of potential risk factors related to their occupation, anthropometric features of respondents, and the level of their physical activity.

Specific objectives:

- To identify the incidence of lumbar and cervical spine pain in physiotherapists.

- To analyze the significance of this medical problem in quantitative terms.

- To describe the most common body positions and activities related to the nature of work causing pain in the examined occupational group.

- To analyze a possible relationship between the occurrence of lumbar and/or cervical spine pain and the nature of the work.

- To determine the degree of disability caused by spinal pain in physiotherapists.

- To assess the influence of physical activity on the occurrence of pain.

The results are to be used in the future to design an exoskeleton supporting physiotherapists at work.

\section{Materials \& Methods}

A total of 240 people (169 females [70.4\%] and 71 males [29.6\%]) licensed to practice as a PT in Poland completed an anonymous questionnaire focused on spinal pain. The study protocol was approved by the Bioethics Committee at the district medical chamber in Gdansk (KB-14/20). The informed consent form was written at the beginning of the test. It was minimizing the possibility of coercion or undue influence, and the subject had sufficient time to consider participation. Research-related information were presented to enable people to voluntarily decide whether or not to participate as a research subject. We advised that the results would be used in medical research and suggested that the answers be honest. An electronic questionnaire was sent to Polish public and non-public medical facilities employing physiotherapists, and to private physiotherapy practices. Participation in the study was declared by 286 physiotherapists. Of these, 16 met the exclusion criteria, and another 30 did not complete the survey. Subjects who were older than 18 years of age, had a valid licence to practice their profession, and actually worked as a physiotherapist were included. Subjects younger than 18 years of age, those with a history of spinal injury, history of spinal surgery, deformities in the spine and/or lower limbs, and pregnant women (due to potential pregnancy-related spinal pain) were excluded from the study. The data were collected using questionnaires: a questionnaire designed by the authors of this study, the Polish version of the Neck Disability Index (NDI) [20], and the Polish version of the Oswestry Disability Index (ODI) [21].

In the questionnaire designed by the authors the respondent defined or described the characteristics of his/her pain. The questions focused on the location of spinal pain (in the cervical, thoracic or lumbar segment), its duration, persistence of symptoms, suspected cause(s), and the reasons for the severity of these ailments. 
131 The nature of the work was described in terms of its duration, the type of activities prevailing 132 during the work, the number of working hours, and the number of years effectively worked. Work 133 done by physiotherapists was categorized into three specialities: kinesiotherapy (movement 134 therapy, therapeutic gymnastics), physical therapy (treatment involving physical stimulation, 135 either natural or produced by devices), and massage. The level of physical activity among 136 respondents (broadly defined recreation) was also determined. Age, body weight and height values 137 of participants were recorded (BMI was calculated). Body mass index (BMI) was calculated as 138 weight $(\mathrm{kg})$ divided by height squared $\left(\mathrm{m}^{2}\right)$.

139 Oswestry is a common condition-specific tool that has been used in over 200 published articles since its inception in 1980 [1,2]. The Polish version of the Neck Disability Index (NDI) was used to assess cervical pain [22]. It consists of 10 questions concerning: pain intensity, care, lifting objects, reading, headache, ability to focus, work, driving, sleeping, and rest. The Polish version of the Oswestry Low Back Pain Disability Index (ODI) was used to assess disability caused by lumbar pain [21]. It contains 10 questions concerning: pain intensity, care, lifting, walking, sitting, standing, sleeping, sexual life, social life, and travelling. In both questionnaires, each question is scored from 0 to 5. All scores are summed and divided into the highest possible score of 45, producing a 0 to 100 -percentage scale, with 0 representing no disability and 100 representing complete disability. For missing responses, the total possible score is reduced (e.g., the highest possible score for 8 responses would be 40). For ease in clinical interpretation, this score was then subtracted from 100 . Thus 0 represents complete disability and 100 represents a normal function. The inversion of the score does not affect any statistical calculations or mathematical relationships.

The aggregate NDI and ODI were presented as a score in the range from 0 to 50 or percentages of $0-100 \%$. Score $0-4(0-8 \%)$ indicated no disability, score 5-14 (10-28\%) indicated minimal disability, score 15-24 (30-48\%) indicated moderate disability, score 25-34 (50-64\%) indicated severe disability, score 35-50 (70-100\%) indicated extreme suffering and disability. Responsiveness is only one characteristic to consider when choosing a survey instrument. For example, Walsh et al. suggested that the ODI is shorter than the SF-36, and if computerized survey administration is not available, it may be easier to administer and score. If ease of administration and scoring is a top priority, then one may choose to utilize the ODI, and responsiveness would not significantly suffer [22]. The cost of such a decision at least includes the loss of general health information, the ability to compare disability between patients with differing conditions, and the possible identification of unintended side effects from the new treatment. The concept of responsiveness is challenging. Beaton et al. have suggested that the responsiveness of an instrument should be viewed within the context of "who" is being studied, "which" scores are being contrasted, and "what" type of change is being assessed [23,24]. The issue of which condition-specific survey is "best" has been studied by Leclaire [25]. The authors prove that the ODI scale measures functional ability. Moreover, according to the authors, the ODI appeared more sensitive in the severely disabled patients than for example Rolland Morris disability scale. ODI may be more suitable for patients with greater limitations. NSN has chosen to utilize the ODI over 
171 population [26,27]. Truthfully, there is no gold standard for measuring change. We agree with the

172 reviewer that questions used to assess spine pain are somewhat generally defined. The questions

173 did not specify a spine problem but did refer to the patient's specific musculoskeletal condition.

174 All statistical calculations were performed using STATISTICA software, version 13.3.

175 (StatSoft, 2020, www.statsoft.com). Quantitative variables were characterized by the mean,

176 standard deviation, median, minimum and maximum values (range) and 95\% CI (confidence

177 interval). Qualitative variables were presented as numbers and percentage values (percentage).

178 Quantitative variables were tested for the normality of distribution using different tests: W

179 Shapiro-Wilk, Lilliefors, Kolmogorov-Smirnov and Jarque-Bera. Statistica package automatically

180 suggests the four types of tests for the normality of distribution The Brown-Forsythe test was used

181 to verify the hypothesis on the equality of variances due to different numbers of variables

182 (disciplines of PT).

183

184

185

186

187

188

189

190

191

192

193

194

195

196

197

198

199

200

201

202

203

204

205

206

207

208

209

210

\section{Results}

The PT group consisted of professionals mainly providing kinesitherapy, physical therapy or massage as part of their work. Basic quantitative data are presented in Table 1.

Near here Table 1

The mean BMI of all PTs was 24.1 (3.4). The mean BMI in women was normal (22.6), while men were slightly overweight (26.0) (Figure 1).

Near here Figure 1

Non-radiating pain in the cervical spine was reported by 67 (29.8\%) respondents, and pain radiating to one limb was reported by 36 respondents $(16.0 \%)$. Radiation to both extremities due to cervical pain was reported by $10(4.4 \%)$ PTs. Non-radiating pain in the thoracic spine was reported by $56(24.9 \%)$ respondents, while radiating pain was reported by 29 respondents $(12.9 \%)$. Pain defined as non-radiating in the lumbar-sacral spine was reported by $110(48.9 \%)$ respondents, radiation to one leg was reported by 83 respondents (36.9\%), while radiation to both legs was reported by 6 respondents $(2.7 \%)$.

Most PTs (125; 55.3\%) scored the last pain episode between 4 (moderate) and 5 (moderate/severe; VAS scale). In the case of kinesitherapy, it was 82 (51.9\%), physical therapy 21 $(56.7 \%)$ and massage $21(46.7 \%)$. Only $57(25.3 \%)$ of all respondents declared more severe pain. The remaining $42(17.9 \%)$ subjects declared very mild to mild/moderate pain. Pain intensity in particular groups is presented in Figure 2.

No painkillers were used by $41.6 \%$ of respondents, $57.1 \%$ used medication when needed, and $1.3 \%$ used low doses on a regular basis. In $40.7 \%$ of respondents the pain did not reduce mobility, in $46.5 \%$ it partially restricted it, in $11.4 \%$ of respondents pain made work difficult, and in $0.9 \%$ of respondents pain prevented independent functioning. Detailed data by speciality are presented in Table 2.

In the case of the cause of pain and the activities that exacerbate it, the sum will not be $100 \%$ since respondents could give more than one answer. The data refer to the whole group.

Near here Figure 2 


\section{Near here Table 2}

The results of the ANOVA test indicated that a zero-hypothesis stating that the mean intensity of the last pain episode (VAS) was similar in individual groups can be accepted at 0.585 . Tukey's post hoc test also confirmed this relationship. A graphical interpretation is presented in Figure 3a. The points correspond to the mean values in the individual groups, and the error bars show confidence limits around the mean. According to the results obtained, the lowest point is the one corresponding to the intensity of the last pain episode among masseurs. The value 3 on the vertical scale indicates mild/moderate pain, while 5 indicates moderate/severe pain. In the case of reduced physical activity, a zero hypothesis can also be accepted for individual groups at 0.770 . Figure $3 \mathrm{~b}$ shows the relationship. On the vertical scale 0 corresponds to no limitation of motor activity, and 1 corresponds to partial limitation.

\section{Near here Figure 3}

The analysis of data obtained from the NDI questionnaire revealed that in the studied group 151 (62.9\%) PTs had no disability related to cervical pain, 66 (27.5\%) had minimal disability, 21 $(8.8 \%)$ had moderate disability, and $2(0.8 \%)$ had severe disability. The results indicated minimal disability due to cervical pain.

The analysis of data obtained from the ODI questionnaire showed that $128(53.3 \%)$ of PTs had no disability due to lumbosacral pain, $100(41.7 \%)$ had minimal disability, $11(4.6 \%)$ had moderate disability, and one $(0.4 \%)$ person had severe disability. Detailed statistics are presented in Table 3.

\section{Near here Table 3}

The Mann-Whitney U test was used to determine the difference in mean values of NDI and ODI between women and men. Based on the calculated test probability of NDI $(p=0.002)$ and ODI $(p=0.024)$, the null hypothesis was rejected, which means that the differences in the mean values of NDI and ODI values between men and women were significant. ANOVA showed that the average difference (median) between men and women in NDI in all groups of PTs was 5, whereas in the case of ODI it was 2. The differences in mean values by sex are presented in Fig. 4a. For women, NDI values were significantly higher than for ODI. NDI and ODI values for men were similar. Figure $4 \mathrm{~b}$ shows a higher mean value for cervical pain in each group than for lumbar pain.

The Mann-Whitney U test was also used to determine the differences in mean values of NDI and ODI between specialities. The obtained values of $p=0.171$ for NDI and $p=0.074$ for ODI indicated the validity of the tested zero hypothesis, which means that the differences in NDI and ODI were not significant between specialities. Results of ANOVA showed that the mean difference in NDI between kinesitherapy and physical therapy was 1.5 , and between kinesitherapy and massage 1 .

\section{Near here Figure 4}

Another analysis was performed (U M-W) to determine the nature of pain and the frequency of its occurrence in individual groups. The calculated value $p=0.995$ indicated the validity of the tested zero hypothesis, which means that differences in pain between specialities were insignificant. The nature and frequency of pain were the same in kinesitherapists and physical 
251 therapists, which means that on average they had one episode of pain per year. Massage therapists

252 experienced pain more often, once a month on average. The test for restriction of physical activity

253 in individual groups $(\mathrm{p}=0.770)$ showed no significant differences, and on average respondents had

254 partially restricted activity due to pain.

255

Figure 5 presents the results of NDI and ODI normality tests in individual specialities. Since at

256

257

least one of the selected tests invalidated the zero hypothesis, the hypothesis about the normality of data distribution was rejected in all cases. The figures show only results of the Shapiro-Wilk

258 test. Considering ODI and the speciality of physical therapy, this test validated the zero hypothesis

259 about the normality of distribution. However, one of the remaining tests rejected the zero

260

261

262 hypotheses.

Using the NW Chi-square test (highest reliability) $(\mathrm{p}=0.285)$ and Pearson's Chi-square test $(p=0.215)$ at the adopted level of significance ( $a l p h a=0.05)$, a significant relationship between work experience (years) and the nature of pain and its frequency was found for all PTs. The results indicated that several episodes of pain were reported most often in PTs with 10-12 years of work experience.

The next step was to determine the correlation between NDI and ODI values, and individual variables at $\mathrm{p}<0.05$. The results obtained for ODI vs. NDI variables indicated a strong positive correlation $\mathrm{r}=0.8532$. There was a weak correlation between work experience and NDI $(\mathrm{r}=0.2700)$, and ODI $(\mathrm{r}=0.2298)$. There was practically no correlation between NDI $(\mathrm{r}=-0.0013)$ and ODI $(\mathrm{r}=0.0600)$ and age of PTs. No correlation was found between NDI $(\mathrm{r}=-0.0013)$, ODI $(\mathrm{r}=0.0600)$ and BMI. A moderate correlation was found between NDI $(\mathrm{r}=0.4369)$ and ODI $(\mathrm{r}=0.5609)$, and the use of painkillers. No correlation was found between work experience and duration of intensive and moderate physical activity.

The analysis of data concerning PTs' physical activity revealed that the majority of the respondents $(76.7 \%)$ declared that during the last 7 days before the study they engaged in vigorous physical exercise causing rapid breathing and heartbeat for at least 10 minutes. These activities included, for example, aerobics, fast cycling or fast running. Kinesitherapists and massage therapists declared doing exercise twice on average, and physical therapists once a week. Only $17.9 \%$ of all respondents indicated that it was 4 times or more per week. In the case of physical therapists and kinesitherapists, the mean time of vigorous exercise was defined as 30-50 minutes, while masseurs declared 10-30 minutes. There was no significant difference between men and women in the amount of exercise per week, while women declared a mean time of exercise of 1030 minutes, while men declared 30-50 minutes.

Moderate/average levels of physical activity, i.e. movement causing a little faster breathing and a faster heartbeat (cycling, playing volleyball, very fast walking), were declared on average as 2 times a week in all groups. The declared mean duration of moderate physical activity was 30-50 minutes in masseurs, and only 10-30 minutes in the group of physical therapists and kinesitherapists. Only $23.3 \%$ of all respondents indicated that it was 4 times or more per week. 
290

291

292

293

294

295

296

297

298

299

300

301

302

303

304

305

306

307

308

309

310

311

312

313

314

315

316

317

318

319

320

321

322

323

324

325

326

327

328

Men preferred a longer duration of moderate physical activity (30-50 minutes) compared to women (10-30 minutes).

The analysis demonstrated that intensive and moderate levels of physical activity 3 times and more per week in the group of physical therapists and massage therapists reduced the frequency of pain episodes (up to a maximum of one per year). Lack of physical activity was associated with an increased number of pain episodes. The mean duration of intensive physical activity from 30 to 50 minutes in the group of masseurs significantly reduced the incidence of pain in this group. The mean exercise time of 30 to 50 minutes reduced the frequency of pain in all examined groups. In the other groups, the frequency and duration of intensive and moderate levels of physical activity did not affect the nature and frequency of pain episodes (Table 4).

Near here Table 4

\section{Discussion}

The results indicate that the pain described by the respondents has a complex aetiology, and several static and dynamic factors contributed to its onset. The analysis showed that NP and/or LBP was reported in all groups of physiotherapists $(91.7 \%)$. The pain was more frequent in the lumbosacral spine $(82 \%)$ than in the cervical spine $(67 \%)$. However, the intensity of pain was higher in the cervical spine.

Our findings are similar to those of other studies carried out in various countries, such as Canada, the USA [28-30], Kuwait [31], the United Kingdom [32], Slovenia [33], Turkey [34], and India [35]. In the USA, the most common work-related locomotor disorder was LBP, which represents $45 \%$ [29]. The lifetime prevalence of work-related pain in Kuwait was $70 \%$ [31]. In Canada, $49 \%$ of PTs reported work-related back pain [28,30]. In India, as many as $92 \%$ of PTs indicated work-related musculoskeletal disorders, where 51\% concerned LBP and $17 \%$ NP [35].

The frequency of musculoskeletal disorders associated with PTs' occupation is high. The resulting pain-related ailments significantly affect everyday activities and sometimes even force the PT to change their profession [35,36]. Mierzejewski and Kumar [36] demonstrated that more than half (55.4\%) of respondents with work-related LBP showed little or no disability. In our study, we observed that as many as $41.7 \%$ of PTs with LBP have minimal disability, while among those with NP $27.5 \%$ had minimal disability and $8.8 \%$ had moderate disability.

Activities such as lifting, tilting and twisting of the abdomen were indicated as the main cause of the first pain episode. Other authors indicated similar results [30,37]. The pain was increased by weightlifting, standing and sitting position, and bending of the abdomen. Unfortunately, PTs' work with the patient mostly requires the above-mentioned postures.

Considering the specific nature of PTs' work in various specialities, we have observed that the incidence of pain from the beginning of their career in kinesitherapists (91.1\%), physical therapists (97.3\%) and masseurs (88.9\%) was at similar levels. Vieira et al. [28] presented another stratification of the study group and reported that the most affected part of the body was the lower part of the back in PTs specializing in emergency care, geriatrics and paediatrics, and the neck in PTs specializing in orthopaedics and neurology. As far as workplaces are concerned, the lower 
329

330

331

332

333

334

335

336

337

338

339

340

341

342

343

344

345

346

347

348

349

350

351

352

353

354

355

356

357

358

359

360

361

362

363

364

365

366

367

368

back was most often affected in PTs working in specialized nursing homes, clinics and hospitals, and the neck in PTs working in academic and home environments.

Our study revealed a significant protective effect of regular exercise on the development of spinal pain. Similar results were observed in previous studies. The lack of regular exercise results in poor or no back support and improper body mechanics [27,38].

A recently published meta-analysis suggests that a moderate to high level of physical activity in leisure time is associated with an 11-16\% reduction in the incidence of episodic or chronic lower back pain [39]. The explanations underlying the protective effects of exercise against chronic lower back pain (LBP) are unclear. Physical exercise in LBP may work by improving posture and muscle activation. However, there is no evidence linking the effects of exercise in LBP with changes in the musculoskeletal system [40]. There is solid evidence that LBP is best understood from a biopsychosocial perspective, as it may involve a combination of psychological, social, lifestyle and physical factors [41].

\section{Conclusions}

In the article we have shown that the profession of a physiotherapist in all specialties is associated with a high risk of pain in the cervical and lumbar spine.

In the entire study group, the incidence of pain in the lumbar spine was higher than that of the pain in the cervical spine. In the entire group of physiotherapists, longer work experience had a significant impact on the occurrence of back pain. There were no significant differences in the intensity of pain sensations between specialties. It has been shown, however, that due to the nature of their work, massage is exposed to a higher frequency of back pain compared to kinesitherapy and physical therapy. This may be due to the lack of compliance with ergonomic standards in the workplace.

In terms of activities causing and increasing the intensity of back pain in all specialties, lifting heavy objects/patients was the most frequently mentioned. Standing, sitting, and bending were listed as subsequent items that increased the occurrence of pain in all specialties. The implementation of preventive measures in the work of these specialists should be considered by teaching them behavioral patterns regarding correct posture and the use of special auxiliary devices. This can be achieved through the regular compulsory training of staff in the use of ancillary equipment and the enforcement of ergonomic standards in the workplace. It also seems reasonable to support the ergonomic aspects of the daily work of physiotherapists. Designers of the exoskeleton supporting the physiotherapist at work should take into account the stresses and pains affecting mainly the cervical and lumbar spine.

The level of disability caused by pain in the cervical or lumbar spine did not differ between specialties. In the entire study group of physiotherapists, the majority did not have disabilities caused by pain in the cervical (62.9\%) and lumbar (53.3\%) spine parts, but a significant percentage had a mild disability in the cervical $(27.5 \%)$ and lumbar parts $(41.7 \%)$ of the spine.

In the entire study group, the frequency and duration of physical activity contributed to a lower number of back pain symptoms. In individual specialties, it has been observed that the greatest 
369 benefits in the form of a smaller number of pain incidents from physical activity occur among 370 massage, then among physical therapy, and the lowest among kinesitherapy. Employers should

371

372

373

374

375

376

377

378

379

380

381

382

383

384

385

386

387

388

389

390

391

392

393

394

395

396

397

398

399

400

401

402

403

404

405

406

407

408 consider supporting physical therapists to improve their health, including organizing physical activity at the workplace as part of physioprophylaxis or preventive rehabilitation. The introduction of exercises aimed at restoring proper muscle tone and behavior minimizing the risk of overload caused by every day and professional activity will certainly lead to a reduction in absenteeism, and thus to an increase in the economic profit of employers.

The limitation of this study is the fact that women and men were not equally represented in the study group. The reason may be that the occupation of PT in Poland is preferred by women.

\section{References NEW}

1. Vassilaki M, Hurwitz EL. 2014. Insights in public health: perspectives on pain in the low back and neck: global burden, epidemiology, and management. Hawai'i journal of medicine \& public health: a journal of Asia Pacific Medicine \& Public Health 73(4):122-126 PMID: 24765562; PMCID: PMC3998232.

2. Hoy D, Bain C, Williams G, March L, Brooks P, Blyth F, Woolf A, Vos T, Buchbinder R. 2012. A systematic review of the global prevalence of low back pain. Arthritis and rheumatism 64(6):2028-2037 doi: 10.1002/art.34347. Epub 2012 Jan 9. PMID: 22231424.

3. Walker BF. 2000. The prevalence of low back pain: a systematic review of the literature from 1966 to 1998. Journal of spinal disorders 13(3):205-217 doi: 10.1097/00002517200006000-00003. PMID: 10872758.

4. Hoy D, March L, Brooks P, Blyth F, Woolf A, Bain C, Williams G, Smith E, Vos T, Barendregt J, Murray C, Burstein R, Buchbinder R. 2010. The global burden of low back pain: estimates from the Global Burden of Disease 2010 study. Annals of the rheumatic diseases 73(6):968-974 doi: 10.1136/annrheumdis-2013-204428. Epub 2014 Mar 24. PMID: 24665116.

5. Steenstra IA, Munhall C, Irvin E, Oranye N, Passmore S, Van Eerd D, Mahood Q, HoggJohnson S. 2017. Systematic Review of Prognostic Factors for Return to Work in Workers with Sub Acute and Chronic Low Back Pain. Journal of occupational rehabilitation 27(3):369-381 doi: 10.1007/s10926-016-9666-x. PMID: 27647141; PMCID: PMC5591348.

6. Glowinski S, Łosiński K, Kowiański P, Waśkow M, Bryndal A, Grochulska A. 2020. Inertial Sensors as a Tool for Diagnosing Discopathy Lumbosacral Pathologic Gait: A Preliminary Research. Diagnostics (Basel) 10(6):342 doi:10.3390/diagnostics10060342

7. Vicente-Herrero M. Teófila, Casal Fuentes Servio Tulio, Espí-López Gemma Victoria, Fernández-Montero Alejandro. 2019. Low back pain in workers. Occupational risk and related variables. Revista Colombiana de Reumatología 26( 4 ): 236-245. Available from: http://www.scielo.org.co/scielo.php?script=sci_arttext\&pid=S0121$81232019000400236 \& \operatorname{lng}=$ en. Epub Nov 01, 2020

8. Marras WS. 2000. Occupational low back disorder causation and control. Ergonomics 43:880-902 doi: 10.1080/001401300409080. PMID: 10929824. 
409

410

411

412

413

414

415

416

417

418

419

420

421

422

423

424

425

426

427

428

429

430

431

432

433

434

435

436

437

438

439

440

441

442

443

444

445

446

447

9. Punnett L, Prüss-Utün A, Nelson DI, Fingerhut MA, Leigh J, Tak S, Phillips S. 2005. Estimating the global burden of low back pain attributable to combined occupational exposures. American journal of industrial medicine 48(6):459-469 doi: 10.1002/ajim.20232. PMID: 16299708.

10. Yang H, Hitchcock E, Haldeman S, Swanson N, Lu ML, Choi B, Nakata A, Baker D. 2016. Workplace psychosocial and organizational factors for neck pain in workers in the United States. American journal of industrial medicine 59(7):549-60 doi: 10.1002/ajim.22602. Epub 2016 May 17. PMID: 27184340; PMCID: PMC4979741.

11. Bryndal A, Wojtysiak M, Moskal J, Lipiec-Kowalska J, Borowczyk M, Tańska M, Grochulska A, Huber J, Majchrzycki M. 2019. Motor Evoked Potentials after Supraspinal Stimulation in Pre- and Postoperative Evaluations of Patients with Cervical Radiculopathy. BioMed research international 6;4576493 doi: 10.1155/2019/4576493. PMID: 31198784; PMCID: PMC6526546.

12. Williams FM, Sambrook PN. 2011. Neck and back pain and intervertebral disc degeneration: role of occupational factors. Best practice \& research. Clinical rheumatology 25(1):69-79 doi: 10.1016/j.berh.2011.01.007. PMID: 21663851.

13. Heuch I, Hagen K, Heuch I, Nygaard Ø, Zwart JA. 2010. The impact of body mass index on the prevalence of low back pain: the HUNT study. Spine (Phila Pa 1976) 35(7):764-8. doi: 10.1097/BRS.0b013e3181ba1531. PMID: 20228714.

14. Bryndal A, Majchrzycki M, Grochulska A, Glowinski S, Seremak-Mrozikiewicz A. 2020. Risk Factors Associated with Low Back Pain among A Group of 1510 Pregnant Women. Journal of Personalized Medicine 10(2):51. Published 2020 Jun 15. doi:10.3390/jpm10020051

15. Adams MA. 2013. Biomechanics of Back Pain. 3rd ed. Edinburgh: Churchill Livingstone/Elsevier

16. Milhem M, Kalichman L, Ezra D, Alperovitch-Najenson D. 2016. Work-related musculoskeletal disorders among physical therapists: A comprehensive narrative review. Int J Occup Med Environ Health 29(5):735-47. doi:10.13075/ijomeh.1896.00620. PMID: 27518884.

17. Campo M, Weiser S, Koenig KL, Nordin M, 2008. Work-Related Musculoskeletal Disorders in Physical Therapists: A Prospective Cohort Study With 1-Year Follow-up, Physical Therapy, 88(5):608-619, https://doi.org/10.2522/ptj.20070127

18. Macintosh JE, Bogduk N. 1991. The attachments of the lumbar erector spinae. Spine (Phila Pa 1976) 16(7):783-92. doi: 10.1097/00007632-199107000-00017. PMID: 1925755.

19. Williams PC. 1955. Examination and conservative treatment for disk lesions of the lower spine. Clinical orthopaedics 5:28-40. PMID: 14379472.

20. Misterska E, Jankowski R, Glowacki M. 2011. Cross-cultural adaptation of the Neck Disability Index and Copenhagen Neck Functional Disability Scale for patients with neck pain due to degenerative and discopathic disorders. Psychometric properties of the Polish 
448

449

450

451

452

453

454

455

456

457

458

459

460

461

462

463

464

465

466

467

468

469

470

471

472

473

474

475

476

477

478

479

480

481

482

483

484

485

486

487

versions. BMC musculoskeletal disorders 12:84. doi: 10.1186/1471-2474-12-84. PMID: $21529360 ;$ PMCID: PMC3108936.

21. Misterska E, Jankowski R, Glowacki M. 2011. Quebec Back Pain Disability Scale, Low Back Outcome Score and revised Oswestry low back pain disability scale for patients with low back pain due to degenerative disc disease: evaluation of Polish versions. Spine (Phila Pa 1976) 36(26):E1722-1729. doi: 10.1097/BRS.0b013e318216ad48. PMID: 21394073.

22. Thomas L, Walsh, et. al. 2003. Is a Condition-Specific Instrument for Patients with Low Back Pain/Leg Symptoms Really Necessary? The Responsiveness of the Oswestry Disability Index, MODEMS, and the SF-36, Spine. 28(6)607-615.

23. Beaton D. 2000. Understanding the relevance of measured change through studies of responsiveness. Spine. 25:3192-3199.

24. Beaton D, Bombardier C, Katz J, et al. 2001. A taxonomy for responsiveness. J Clin Epidemiol. 54:1204-17.

25. Leclaire R, Blier F, Fortin L, et al. 1997. A cross-sectional study comparing Oswestry and Roland-Morris functional disability scales in two populations of patients with low back pain of differing levels of severity. Spine. 22:68 -71.

26. Bryndal A, Majchrzycki M, Grochulska A, Glowinski S, Seremak-Mrozikiewicz A. 2020. Risk factors associated with low back pain among a group of 1510 pregnant women. J. Pers. Med. 10(2), 51

27. Glowinski, S., Krzyzynski T. 2013. Modelling on ejection process in a symmetrical flight. Journal of Theoretical and Applied Mechanics 51(3):775-785

28. Vieira ER, Svoboda S, Belniak A, Brunt D, Rose-St Prix C, Roberts L, da Costa BR. 2016. Work-related musculoskeletal disorders among physical therapists: an online survey.

Disability and rehabilitation 38(6):552-557. doi: 10.3109/09638288.2015.1049375. Epub 2015 May 26. PMID: 26007284.

29. Bork BE, Cook TM, Rosecrance JC, Engelhardt KA, Thomason ME, Wauford IJ, Worley RK. 1996. Work-related musculoskeletal disorders among physical therapists. Physical therapy 76(8):827-835. doi: 10.1093/ptj/76.8.827. PMID: 8710962.

30. Campo M, Weiser S, Koenig KL, Nordin M. 2008. Work-related musculoskeletal disorders in physical therapists: a prospective cohort study with 1-year follow-up. Physical Therapy 88(5):608-619. doi:10.2522/ptj.20070127

31. Shehab D, Al-Jarallah K, Moussa MA, Adham N. 2003. Prevalence of low back pain among physical therapists in Kuwait. Medical principles and practice : international journal of the Kuwait University, Health Science Centre 12(4):224-230. doi: 10.1159/000072288. PMID: 12966194.

32. Scholey M, Hair M. 1989. Back pain in physiotherapists involved in back care education. Ergonomics 32(2):179-90. doi: 10.1080/00140138908966078. PMID: 2523797.

33. Rugelj D. 2003. Low back pain and other work-related musculoskeletal problems among physiotherapists. Applied ergonomics 34(6):635-639. doi: 10.1016/S0003-6870(03)00059-0. PMID: 14559425. 
488

489

490

491

492

493

494

495

496

497

498

499

500

501

502

503

504

505

506

507

508

509

510

511

512

513

514

515

34. Molumphy M, Unger B, Jensen GM, Lopopolo RB. 1985. Incidence of work-related low back pain in physical therapists. Physical Therapy 65(4):482-6. doi: 10.1093/ptj/65.4.482. PMID: 3157196.

35. Iqbal Z, Alghadir A. 2015. Prevalence of work-related musculoskeletal disorders among physical therapists. Medycyna Pracy 66(4):459-69. doi: 10.13075/mp.5893.00142. PMID: 26536963.

36. Mierzejewski M, Kumar S. 1997. Prevalence of low back pain among physical therapists in Edmonton, Canada. Disability and rehabilitation 19(8):309-17. doi: 10.3109/09638289709166544. PMID: 9279486.

37. Scholey M, Hair MD. 1989. The problem of back pain in physiotherapists. Physiotherapy Practice 5(4), 183-192, DOI: 10.3109/09593988909037772

38. Terzi R, Altın F. 2015. The prevalence of low back pain in hospital staff and its relationship with chronic fatigue syndrome and occupational factors. Agri: Agri (Algoloji) Dernegi'nin Yayin organidir The journal of the Turkish Society of Algology 27(3):149-154.

39. Shiri R, Falah-Hassani K. 2017. Does leisure time physical activity protect against low back pain? Systematic review and meta-analysis of 36 prospective cohort studies. British journal of sports medicine 51(19):1410-1418. doi: 10.1136/bjsports-2016-097352. Epub 2017 Jun 14. PMID: 28615218.

40. Halliday MH, Pappas E, Hancock MJ, Clare HA, Pinto RZ, Robertson G, Ferreira PH. 2016. A Randomized Controlled Trial Comparing the McKenzie Method to Motor Control Exercises in People with Chronic Low Back Pain and a Directional Preference. The Journal of orthopaedic and sports physical therapy 46(7):514-522. doi: 10.2519/jospt.2016.6379. Epub 2016 May 12. PMID: 27170524.

41. Kamper SJ, Apeldoorn AT, Chiarotto A, Smeets RJ, Ostelo RW, Guzman J, van Tulder MW. 2015. Multidisciplinary biopsychosocial rehabilitation for chronic low back pain: Cochrane systematic review and meta-analysis. BMJ (Clinical research ed.) 350:h444. doi: 10.1136/bmj.h444. PMID: 25694111; PMCID: PMC4353283.

Peer] reviewing PDF | (2020:08:52000:2:1:NEW 10 Jun 2021) 
516 Table 1.

\begin{tabular}{|c|c|c|c|c|c|}
\hline Variable & $\begin{array}{c}\text { women } \\
\text { men }\end{array}$ & $\begin{array}{c}\text { All groups } \\
\text { (N=240) } \\
169(70.5 \%) \\
71(29.5 \%)\end{array}$ & $\begin{array}{c}\text { Kinesitherapy } \\
(\mathbf{n}=\mathbf{1 5 8}) \\
109(69.0 \%) \\
49(31 \%)\end{array}$ & $\begin{array}{c}\text { Physical therapy } \\
(\mathbf{n}=\mathbf{3 7}) \\
28(75.7 \%) \\
9(24.3 \%)\end{array}$ &  \\
\hline & & $\begin{array}{c}\text { mean }(\mathrm{SD}) ; \\
\text { med; [min; max }]\end{array}$ & $\begin{array}{c}\text { mean (SD); } \\
\text { med; [min; max] }\end{array}$ & $\begin{array}{c}\text { mean }(\mathrm{SD}) ; \\
\text { med; }[\min ; \max ]\end{array}$ & $\begin{array}{c}\text { mean (SD); } \\
\text { med; [min; max] }\end{array}$ \\
\hline \multirow[t]{2}{*}{ Age [years] } & & $\begin{array}{l}38.7(11.0) \\
35 ;[19 ; 63]\end{array}$ & $\begin{array}{l}39.1(11.1) \\
36 ;[19 ; 63]\end{array}$ & $\begin{array}{l}32.8(5.5) \\
34 ;[23 ; 47]\end{array}$ & $\begin{array}{l}42.2(11.9) \\
38 ;[22 ; 61]\end{array}$ \\
\hline & $\begin{array}{c}\text { women } \\
\text { men }\end{array}$ & $\begin{array}{c}40.3(11.4) \\
35.0(8.9)\end{array}$ & & & \\
\hline \multirow[t]{2}{*}{ Height $[\mathrm{cm}]$} & & $\begin{array}{c}171.0(8.6) ; \\
170 ;[153 ; 199]\end{array}$ & $\begin{array}{c}170.9(8.7) \\
170 ;[153 ; 199]\end{array}$ & $\begin{array}{c}171.4(8.0) ; \\
170 ;[159 ; 189]\end{array}$ & $\begin{array}{c}170.7(8.7) \\
170 ;[155 ; 198]\end{array}$ \\
\hline & $\begin{array}{l}\text { women } \\
\text { men }\end{array}$ & $\begin{array}{l}167.1(5.9) \\
180.3(6.6)\end{array}$ & & & \\
\hline \multirow[t]{2}{*}{ Weight $[\mathrm{kg}]$} & & $\begin{array}{c}79.9(13.9) \\
67 ;[42 ; 120]\end{array}$ & $\begin{array}{l}70.8(13.7) \\
68 ;[43 ; 120]\end{array}$ & $\begin{array}{l}69.8(14.6) \\
64 ;[52 ; 105]\end{array}$ & $\begin{array}{c}72.0(14.5) \\
68 ;[42 ; 112]\end{array}$ \\
\hline & $\begin{array}{l}\text { women } \\
\text { men }\end{array}$ & $\begin{array}{c}64.5(8.9) \\
86.1(11.8)\end{array}$ & & & \\
\hline \multirow[t]{2}{*}{ Employment [years] } & & $\begin{array}{l}15.1(11.8) \\
12 ;[1 ; 42]\end{array}$ & $\begin{array}{l}15.3(11.7) \\
12 ;[1 ; 40]\end{array}$ & $\begin{array}{l}8.4(5.2) \\
9 ;[1 ; 18]\end{array}$ & $\begin{array}{l}19.7(13.6) \\
15 ;[1 ; 42]\end{array}$ \\
\hline & $\begin{array}{l}\text { women } \\
\text { men }\end{array}$ & $\begin{array}{l}15.1(11.8) \\
11.5(8.8)\end{array}$ & & & \\
\hline \multicolumn{2}{|l|}{$\begin{array}{r}\text { Work time per day } \\
\text { less than } 6 \\
\text { from } 6 \text { to } 8 \\
\text { over } 8\end{array}$} & $\begin{array}{c}46(19.2 \%) \\
139(57.9 \%) \\
55(22.9 \%)\end{array}$ & $\begin{array}{l}30(19.0 \%) \\
89(56.3 \%) \\
39(24.7 \%)\end{array}$ & $\begin{array}{c}9(24.4 \%) \\
16(43.2 \%) \\
12(32.4 \%)\end{array}$ & $\begin{array}{c}7(15.6 \%) \\
34(75.6 \%) \\
4(8.8 \%)\end{array}$ \\
\hline $\begin{array}{r}\text { less than } 6 \\
\text { from } 6 \text { to } 8 \\
\text { over } 8\end{array}$ & $\begin{array}{c}\text { women } \\
\text { men } \\
\text { women } \\
\text { men } \\
\text { women } \\
\text { men }\end{array}$ & $\begin{array}{c}36(21.3 \%) \\
10(14.1 \%) \\
110(56.1 \%) \\
29(40.8 \%) \\
23(13.6 \%) \\
32(45.1 \%)\end{array}$ & & & \\
\hline
\end{tabular}


518 Table 2.

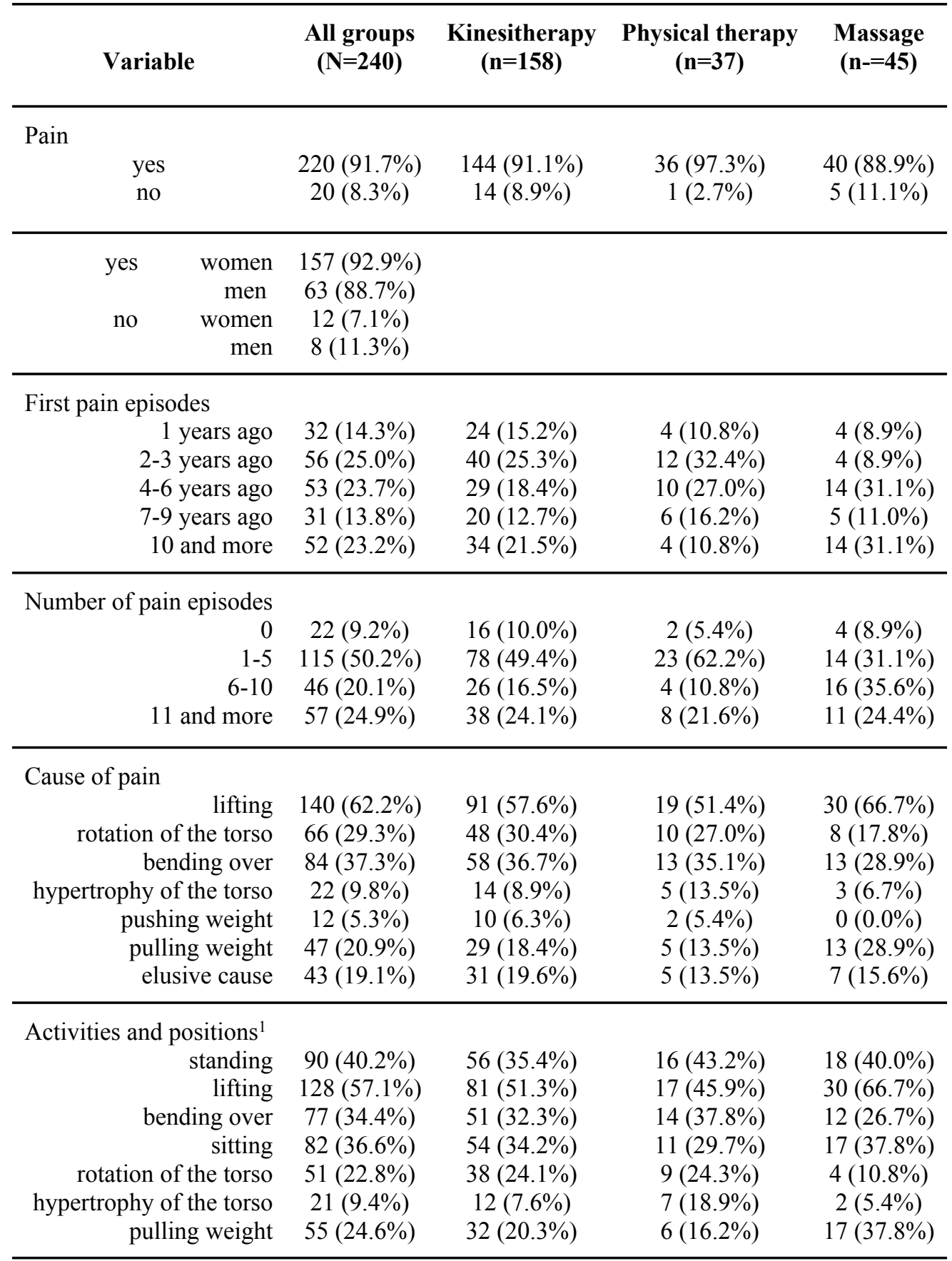

${ }^{1}$ Activities and positions that intensify pain 


\section{Table 3}

522

\begin{tabular}{|c|c|c|c|c|c|c|}
\hline & \multicolumn{3}{|c|}{$\underset{(n=161)}{\text { NDI }}$} & \multicolumn{3}{|c|}{$\underset{(n=196)}{\text { ODI }}$} \\
\hline & \multicolumn{3}{|c|}{$\begin{array}{c}\text { mean }(\mathrm{SD}) ; \\
\text { med; [min; max] }\end{array}$} & \multicolumn{3}{|c|}{$\begin{array}{c}\text { mean }(\mathrm{SD}) ; \\
\text { med; [min; max] }\end{array}$} \\
\hline \multirow[t]{2}{*}{$\begin{array}{l}\text { All groups } \\
(\mathrm{N}=240)\end{array}$} & $\begin{array}{l}8.1(6.3) \\
7 ;[0 ; 26]\end{array}$ & $\begin{array}{c}\text { Men } \\
(\mathrm{n}=33)\end{array}$ & $\begin{array}{l}5.7(6.0) \\
3 ;[0 ; 24]\end{array}$ & $\begin{array}{l}6.0(4.9) \\
5 ;[0 ; 25]\end{array}$ & $\begin{array}{c}\text { Men } \\
(\mathrm{n}=60)\end{array}$ & $\begin{array}{l}5.0(4.9) ; \\
4 ;[0 ; 25]\end{array}$ \\
\hline & & $\begin{array}{l}\text { Woman } \\
(\mathrm{n}=128)\end{array}$ & $\begin{array}{l}8.8(6.2) \\
8 ;[0 ; 26]\end{array}$ & & $\begin{array}{l}\text { Woman } \\
(\mathrm{n}=136)\end{array}$ & $\begin{array}{l}6.4(4.8) ; \\
6 ;[0 ; 22]\end{array}$ \\
\hline \multirow[t]{2}{*}{$\begin{array}{l}\text { Kinesitherapy } \\
\quad(\mathrm{n}=158)\end{array}$} & $\begin{array}{l}7.7(5.5) \\
7 ;[0 ; 24]\end{array}$ & $\begin{array}{c}\text { Men } \\
(n=19)\end{array}$ & $\begin{array}{c}6.2(6.4) \\
3.5 ;[0 ; 24]\end{array}$ & $\begin{array}{l}5.6(4.2) \\
5 ;[0 ; 25]\end{array}$ & $\begin{array}{c}\text { Men } \\
(\mathrm{n}=41)\end{array}$ & $\begin{array}{l}5.1(4.6) ; \\
4 ;[0 ; 25]\end{array}$ \\
\hline & & $\begin{array}{l}\text { Woman } \\
(\mathrm{n}=90)\end{array}$ & $\begin{array}{l}7.6(5.6) \\
7 ;[0 ; 24]\end{array}$ & & $\begin{array}{l}\text { Woman } \\
(\mathrm{n}=87)\end{array}$ & $\begin{array}{l}5.8(4.1) ; \\
5 ;[0 ; 18]\end{array}$ \\
\hline \multirow[t]{2}{*}{$\begin{array}{l}\text { Physical therapy } \\
\qquad(\mathrm{n}=37)\end{array}$} & $\begin{array}{l}10.3(7.9) \\
9.5 ;[2 ; 26]\end{array}$ & $\begin{array}{l}\text { Men } \\
(\mathrm{n}=2)\end{array}$ & $\begin{array}{l}3.5(2.1) \\
3.5 ;[2 ; 5]\end{array}$ & $\begin{array}{l}7.4(5.2) \\
6 ;[0 ; 17]\end{array}$ & $\begin{array}{l}\text { Men } \\
(\mathrm{n}=4)\end{array}$ & $\begin{array}{l}5.5(2.9) ; \\
5.5 ;[2 ; 9]\end{array}$ \\
\hline & & $\begin{array}{l}\text { Woman } \\
(\mathrm{n}=18)\end{array}$ & $\begin{array}{c}11.1(7.9) \\
11.5 ;[2 ; 26]\end{array}$ & & $\begin{array}{l}\text { Woman } \\
(\mathrm{n}=29)\end{array}$ & $\begin{array}{l}7.7(5.5) ; \\
8 ;[0 ; 17]\end{array}$ \\
\hline \multirow[t]{2}{*}{$\begin{array}{l}\text { Massage } \\
(n=45)\end{array}$} & $\begin{array}{l}8.1(7.1) \\
6 ;[0 ; 23]\end{array}$ & $\begin{array}{c}\text { Men } \\
(\mathrm{n}=12)\end{array}$ & $\begin{array}{l}5.3(5.9) \\
3 ;[0 ; 17]\end{array}$ & $\begin{array}{l}5.9(6.4) ; \\
5 ;[0 ; 22]\end{array}$ & $\begin{array}{c}\text { Men } \\
(\mathrm{n}=15)\end{array}$ & $\begin{array}{l}4.7(6.4) ; \\
3 ;[0 ; 22]\end{array}$ \\
\hline & & $\begin{array}{l}\text { Woman } \\
(\mathrm{n}=20)\end{array}$ & $\begin{array}{c}9.8(7.4) \\
8.5 ;[0 ; 23]\end{array}$ & & $\begin{array}{l}\text { Woman } \\
(\mathrm{n}=20)\end{array}$ & $\begin{array}{l}6.8(6.3) ; \\
6 ;[0 ; 22]\end{array}$ \\
\hline
\end{tabular}

NDI - Neck Disability Index; ODI - Oswestry Low Back Pain Disability Index 
Figure 1

Box plot representation of the distribution of physiotherapists' Body Mass Index (a) BMI vs Sex (b) BMI vs specialization (physical therapy, kinesitherapy, massage).
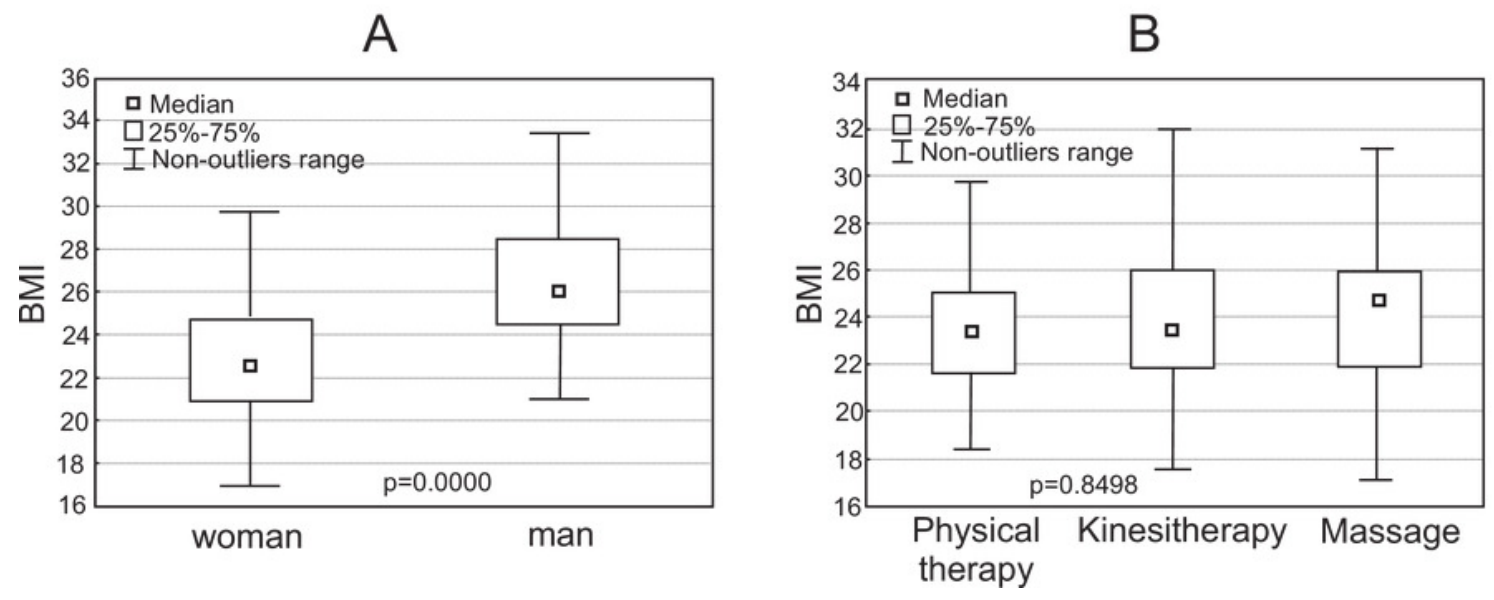
Figure 2

\section{Box plot representation of pain intensity}
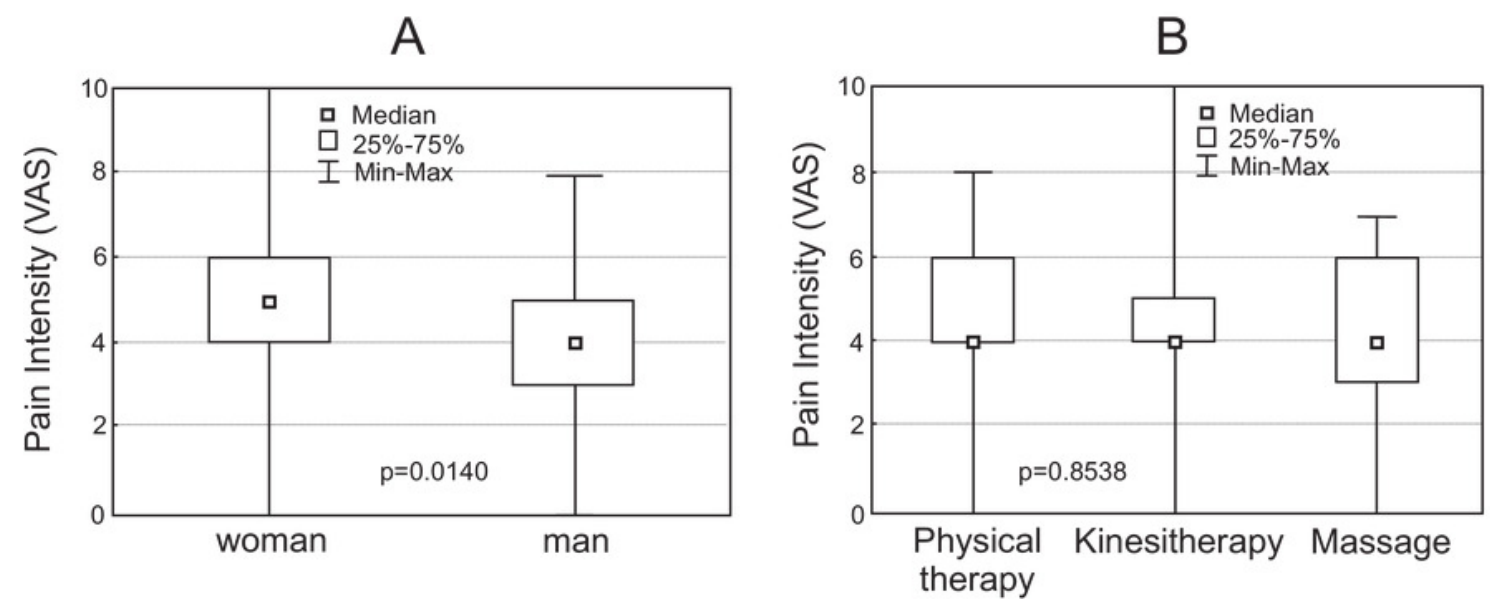
Figure 3

Mean and 95.00\% Confidence intervals: (a) Last pain intensity (VAS) (b) Limitation of physical activity.

Figure 4

NDI and ODI: woman and man (A) physical therapy, kinesitherapy, massage (B)

NDI and ODI: woman and man (A) physical therapy, kinesitherapy, massage (B)

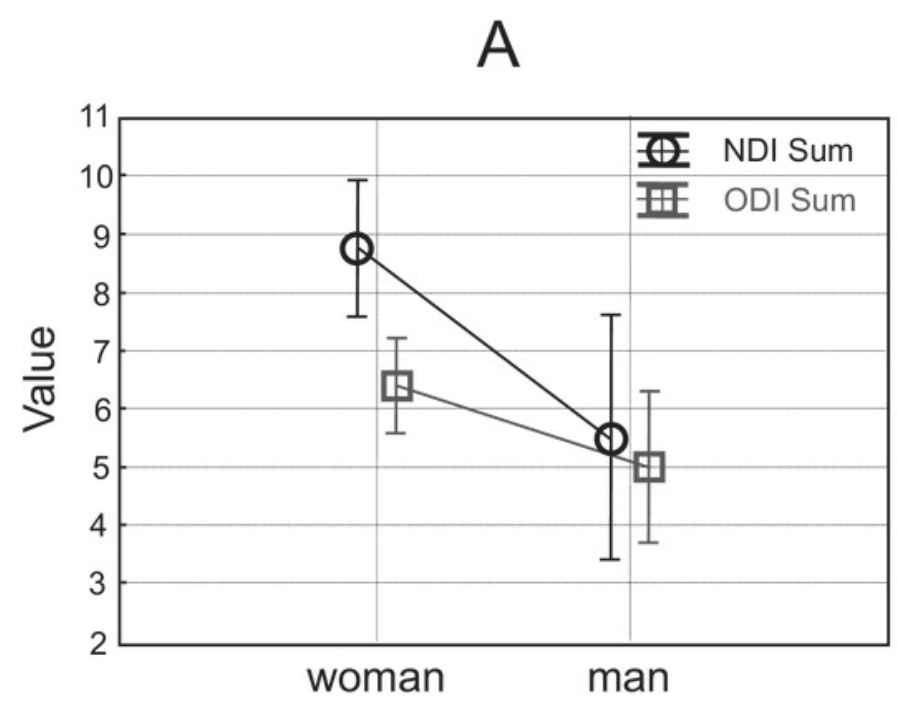

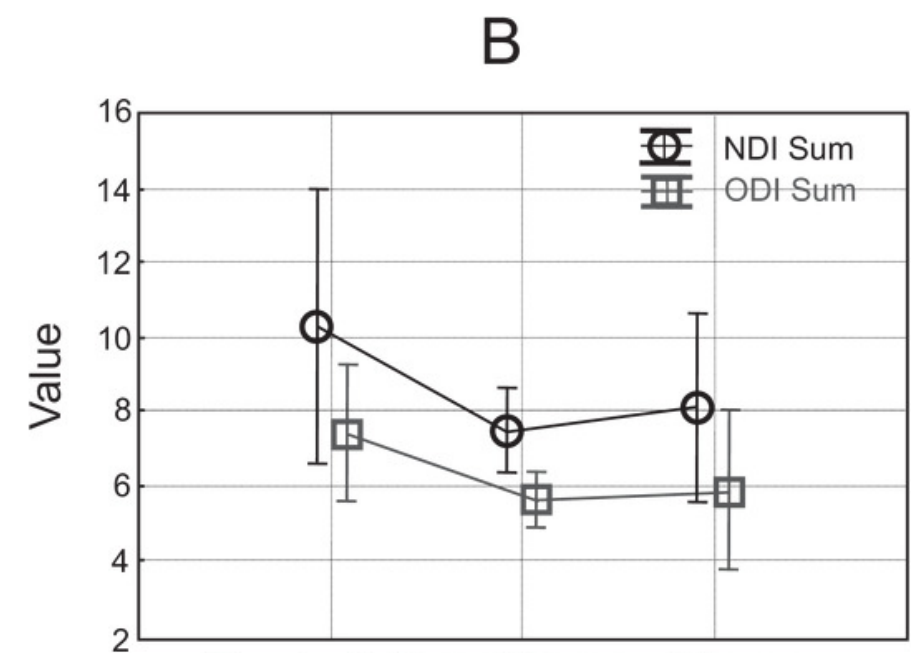

Physical Kinesitherapy Massage therapy 
Figure 5

NDI and ODI plot normality (A) NDI Physical Therapy (B) NDI Kinesitherapy (C) ODI

Physical Therapy (D) ODI Kinesitherapy (E) NDI Massage (F) ODI Massage 
A

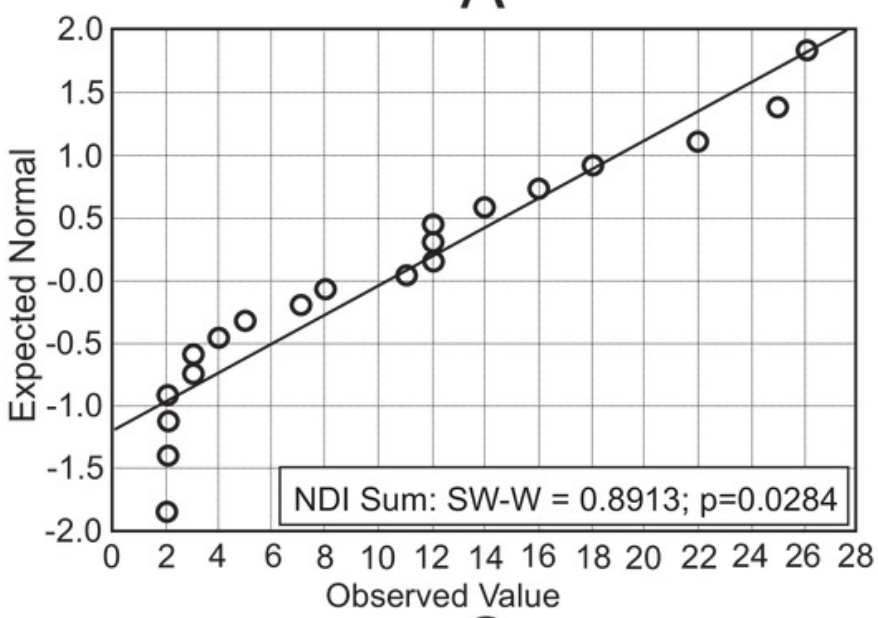

C

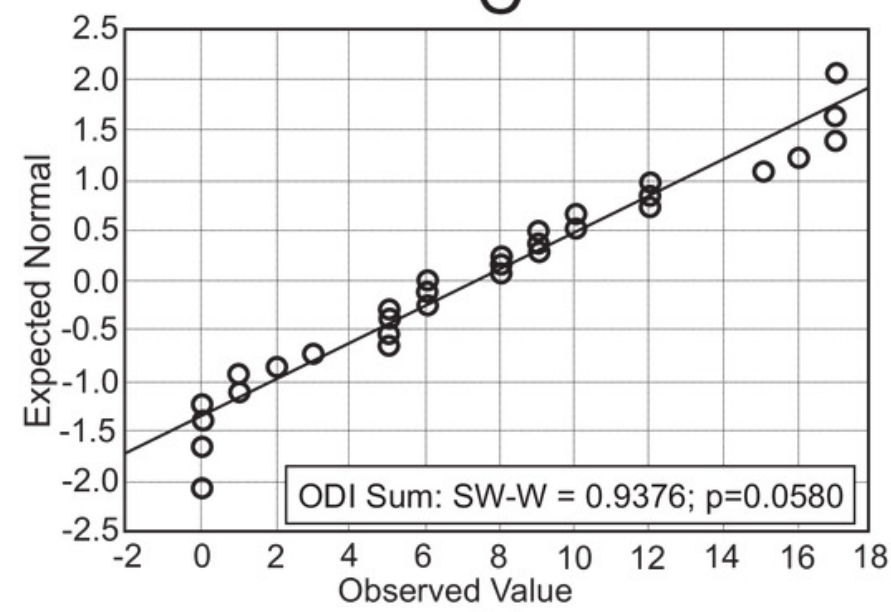

E

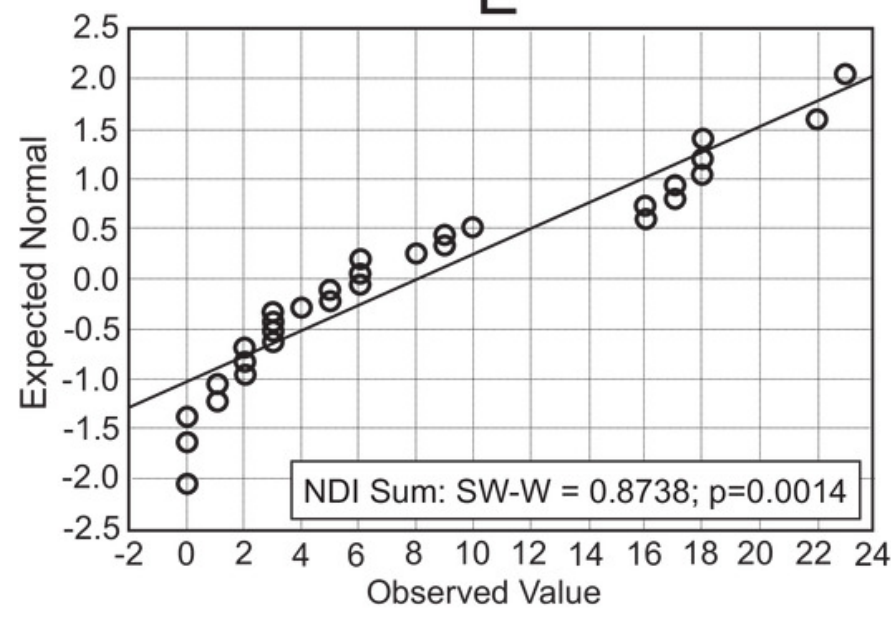

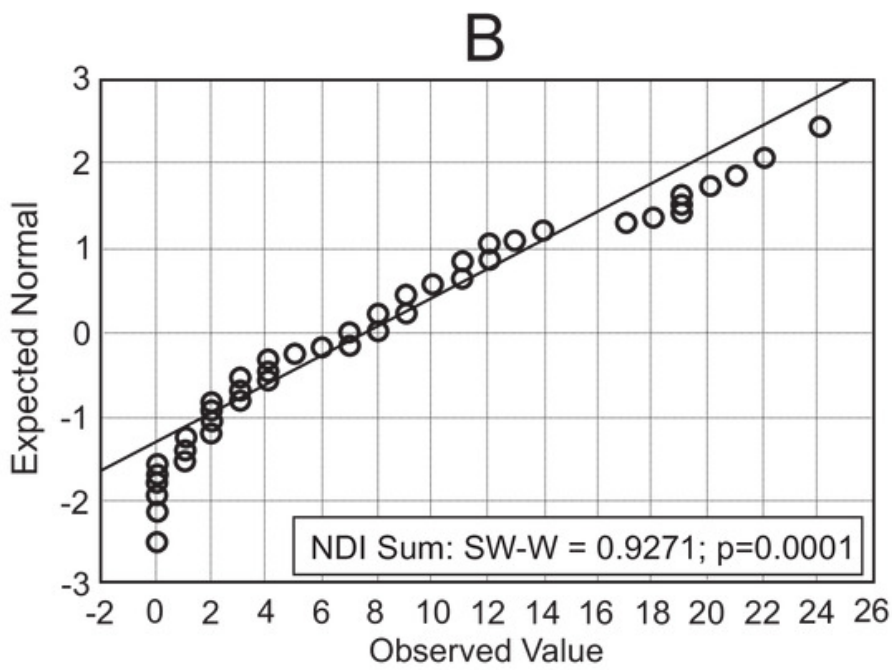

D



$\mathrm{F}$

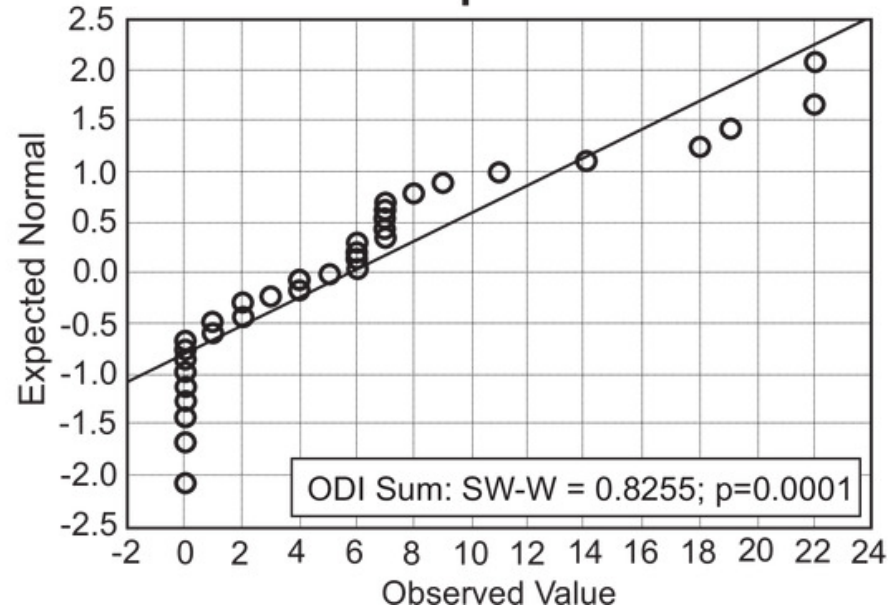




\section{Table 1 (on next page)}

Characteristics of the study group by speciality 


\begin{tabular}{|c|c|c|c|c|c|}
\hline Variable & $\begin{array}{c}\text { women } \\
\text { men }\end{array}$ & $\begin{array}{c}\text { All groups } \\
(\mathbf{N}=\mathbf{2 4 0}) \\
169(70.5 \%) \\
71(29.5 \%)\end{array}$ & $\begin{array}{c}\begin{array}{c}\text { Kinesitherapy } \\
(\mathbf{n}=\mathbf{1 5 8})\end{array} \\
109(69.0 \%) \\
49(31 \%)\end{array}$ & $\begin{array}{c}\begin{array}{c}\text { Physical therapy } \\
(\mathbf{n}=\mathbf{3 7})\end{array} \\
28(75.7 \%) \\
9(24.3 \%)\end{array}$ & $\begin{array}{c}\begin{array}{c}\text { Massage } \\
(\mathbf{n}-=\mathbf{4 5})\end{array} \\
32(71.1 \%) \\
13(28.9 \%)\end{array}$ \\
\hline & & $\begin{array}{c}\text { mean }(\mathrm{SD}) ; \\
\text { med; [min; max }]\end{array}$ & $\begin{array}{c}\text { mean (SD); } \\
\text { med; [min; max] }\end{array}$ & $\begin{array}{c}\text { mean }(\mathrm{SD}) ; \\
\text { med; }[\min ; \max ]\end{array}$ & $\begin{array}{c}\text { mean (SD); } \\
\text { med; [min; max] }\end{array}$ \\
\hline Age [years] & & $\begin{array}{l}38.7(11.0) \\
35 ;[19 ; 63]\end{array}$ & $\begin{array}{l}39.1(11.1) \\
36 ;[19 ; 63]\end{array}$ & $\begin{array}{c}32.8(5.5) \\
34 ;[23 ; 47]\end{array}$ & $\begin{array}{l}42.2(11.9) ; \\
38 ;[22 ; 61]\end{array}$ \\
\hline & $\begin{array}{l}\text { women } \\
\text { men }\end{array}$ & $\begin{array}{c}40.3(11.4) \\
35.0(8.9)\end{array}$ & & & \\
\hline Height $[\mathrm{cm}]$ & & $\begin{array}{c}171.0(8.6) \\
170 ;[153 ; 199]\end{array}$ & $\begin{array}{c}170.9(8.7) \\
170 ;[153 ; 199]\end{array}$ & $\begin{array}{c}171.4(8.0) ; \\
170 ;[159 ; 189]\end{array}$ & $\begin{array}{c}170.7(8.7) \\
170 ;[155 ; 198]\end{array}$ \\
\hline & $\begin{array}{c}\text { women } \\
\text { men }\end{array}$ & $\begin{array}{l}167.1(5.9) \\
180.3(6.6)\end{array}$ & & & \\
\hline Weight $[\mathrm{kg}]$ & & $\begin{array}{l}79.9(13.9) \\
67 ;[42 ; 120]\end{array}$ & $\begin{array}{l}70.8(13.7) \\
68 ;[43 ; 120]\end{array}$ & $\begin{array}{l}69.8(14.6) \\
64 ;[52 ; 105]\end{array}$ & $\begin{array}{l}72.0(14.5) \\
68 ;[42 ; 112]\end{array}$ \\
\hline & $\begin{array}{l}\text { women } \\
\text { men }\end{array}$ & $\begin{array}{c}64.5(8.9) \\
86.1(11.8)\end{array}$ & & & \\
\hline Employment [years] & & $\begin{array}{l}15.1(11.8) \\
12 ;[1 ; 42]\end{array}$ & $\begin{array}{l}15.3(11.7) \\
12 ;[1 ; 40]\end{array}$ & $\begin{array}{l}8.4(5.2) \\
9 ;[1 ; 18]\end{array}$ & $\begin{array}{l}19.7(13.6) \\
15 ;[1 ; 42]\end{array}$ \\
\hline & $\begin{array}{l}\text { women } \\
\text { men }\end{array}$ & $\begin{array}{l}15.1(11.8) \\
11.5(8.8)\end{array}$ & & & \\
\hline $\begin{array}{r}\text { Work time per day } \\
\text { less than } 6 \\
\text { from } 6 \text { to } 8 \\
\text { over } 8\end{array}$ & & $\begin{array}{c}46(19.2 \%) \\
139(57.9 \%) \\
55(22.9 \%)\end{array}$ & $\begin{array}{l}30(19.0 \%) \\
89(56.3 \%) \\
39(24.7 \%)\end{array}$ & $\begin{array}{l}9(24.4 \%) \\
16(43.2 \%) \\
12(32.4 \%)\end{array}$ & $\begin{array}{c}7(15.6 \%) \\
34(75.6 \%) \\
4(8.8 \%)\end{array}$ \\
\hline $\begin{array}{r}\text { less than } 6 \\
\text { from } 6 \text { to } 8 \\
\text { over } 8\end{array}$ & $\begin{array}{c}\text { women } \\
\text { men } \\
\text { women } \\
\text { men } \\
\text { women } \\
\text { men }\end{array}$ & $\begin{array}{c}36(21.3 \%) \\
10(14.1 \%) \\
110(56.1 \%) \\
29(40.8 \%) \\
23(13.6 \%) \\
32(45.1 \%)\end{array}$ & & & \\
\hline
\end{tabular}


Table 2 (on next page)

Characteristics of the group with a breakdown by speciality in terms of the occurrence of pain 


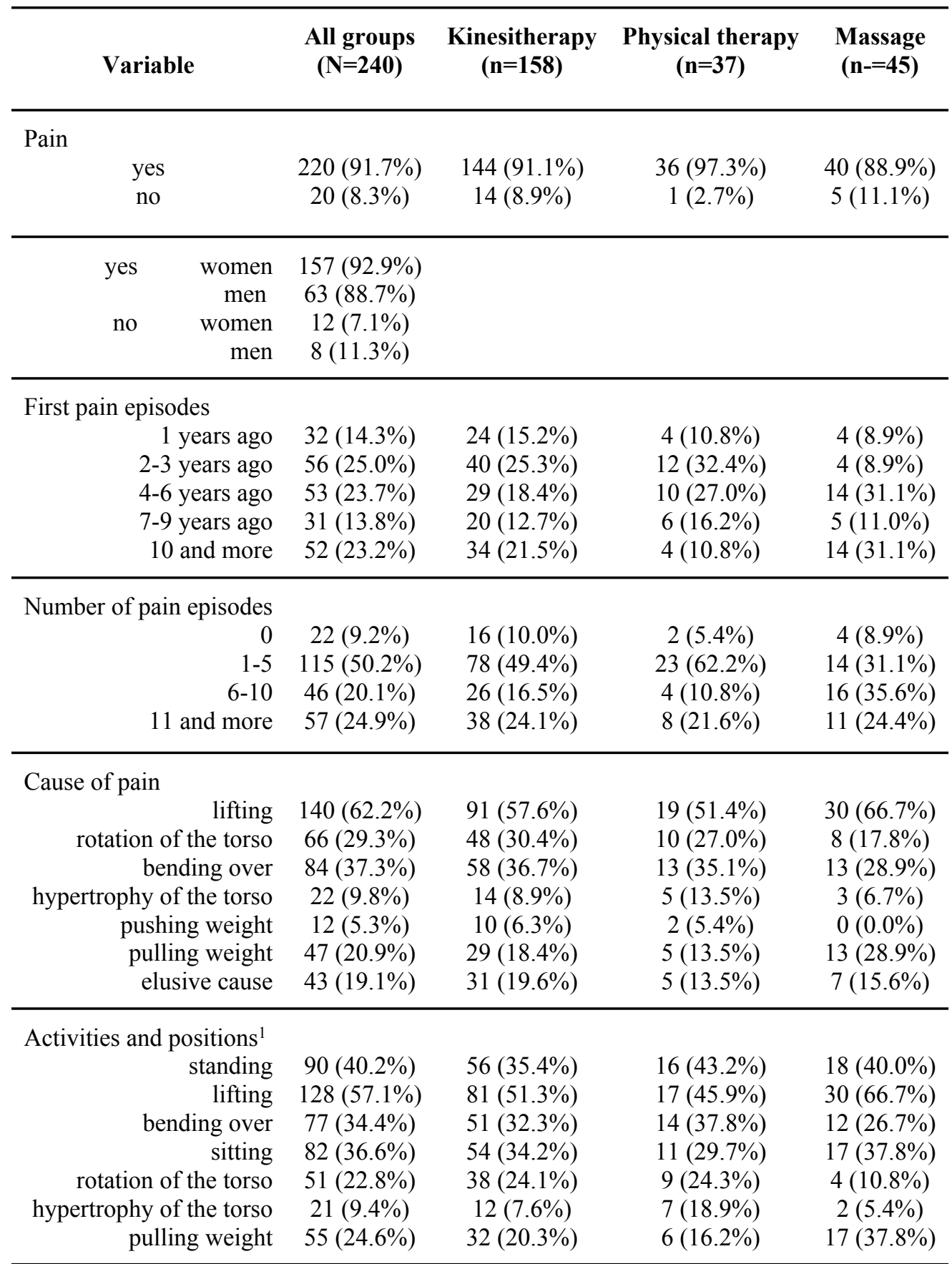

${ }^{1}$ Activities and positions that intensify pain 


\section{Table 3(on next page)}

Results of NDI and ODI in the study group and by speciality 


\begin{tabular}{|c|c|c|c|c|c|c|}
\hline & \multicolumn{3}{|c|}{$\begin{array}{c}\text { NDI } \\
(\mathrm{n}=161)\end{array}$} & \multicolumn{3}{|c|}{$\underset{(\mathrm{n}=196)}{\text { ODI }}$} \\
\hline & \multicolumn{3}{|c|}{$\begin{array}{c}\text { mean (SD); } \\
\text { med; [min; max] }\end{array}$} & \multicolumn{3}{|c|}{$\begin{array}{c}\text { mean }(\mathrm{SD}) ; \\
\text { med; [min; max] }\end{array}$} \\
\hline \multirow[t]{2}{*}{$\begin{array}{l}\text { All groups } \\
(\mathrm{N}=240)\end{array}$} & $\begin{array}{l}8.1(6.3) \\
7 ;[0 ; 26]\end{array}$ & $\begin{array}{c}\text { Men } \\
(n=33)\end{array}$ & $\begin{array}{l}5.7(6.0) \\
3 ;[0 ; 24]\end{array}$ & $\begin{array}{l}6.0(4.9) \\
5 ;[0 ; 25]\end{array}$ & $\begin{array}{c}\text { Men } \\
(\mathrm{n}=60)\end{array}$ & $\begin{array}{l}5.0(4.9) ; \\
4 ;[0 ; 25]\end{array}$ \\
\hline & & $\begin{array}{l}\text { Woman } \\
(\mathrm{n}=128)\end{array}$ & $\begin{array}{l}8.8(6.2) \\
8 ;[0 ; 26]\end{array}$ & & $\begin{array}{r}\text { Woman } \\
(n=136)\end{array}$ & $\begin{array}{l}6.4(4.8) ; \\
6 ;[0 ; 22]\end{array}$ \\
\hline \multirow[t]{2}{*}{$\begin{array}{l}\text { Kinesitherapy } \\
\quad(\mathrm{n}=158)\end{array}$} & $\begin{array}{l}7.7(5.5) \\
7 ;[0 ; 24]\end{array}$ & $\begin{array}{c}\text { Men } \\
(\mathrm{n}=19)\end{array}$ & $\begin{array}{c}6.2(6.4) \\
3.5 ;[0 ; 24]\end{array}$ & $\begin{array}{l}5.6(4.2) \\
5 ;[0 ; 25]\end{array}$ & $\begin{array}{c}\text { Men } \\
(\mathrm{n}=41)\end{array}$ & $\begin{array}{l}5.1(4.6) ; \\
4 ;[0 ; 25]\end{array}$ \\
\hline & & $\begin{array}{l}\text { Woman } \\
(\mathrm{n}=90)\end{array}$ & $\begin{array}{l}7.6(5.6) \\
7 ;[0 ; 24]\end{array}$ & & $\begin{array}{c}\text { Woman } \\
(\mathrm{n}=87)\end{array}$ & $\begin{array}{l}5.8(4.1) ; \\
5 ;[0 ; 18]\end{array}$ \\
\hline \multirow[t]{2}{*}{$\begin{array}{l}\text { Physical therapy } \\
\qquad(\mathrm{n}=37)\end{array}$} & $\begin{array}{l}10.3(7.9) ; \\
9.5 ;[2 ; 26]\end{array}$ & $\begin{array}{l}\text { Men } \\
(\mathrm{n}=2)\end{array}$ & $\begin{array}{l}3.5(2.1) \\
3.5 ;[2 ; 5]\end{array}$ & $\begin{array}{l}7.4(5.2) \\
6 ;[0 ; 17]\end{array}$ & $\begin{array}{l}\text { Men } \\
(n=4)\end{array}$ & $\begin{array}{l}5.5(2.9) ; \\
5.5 ;[2 ; 9]\end{array}$ \\
\hline & & $\begin{array}{l}\text { Woman } \\
(\mathrm{n}=18)\end{array}$ & $\begin{array}{c}11.1(7.9) \\
11.5 ;[2 ; 26]\end{array}$ & & $\begin{array}{l}\text { Woman } \\
(\mathrm{n}=29)\end{array}$ & $\begin{array}{l}7.7(5.5) ; \\
8 ;[0 ; 17]\end{array}$ \\
\hline \multirow[t]{2}{*}{$\begin{array}{l}\text { Massage } \\
(\mathrm{n}=45)\end{array}$} & $\begin{array}{l}8.1(7.1) ; \\
6 ;[0 ; 23]\end{array}$ & $\begin{array}{c}\text { Men } \\
(\mathrm{n}=12)\end{array}$ & $\begin{array}{l}5.3(5.9) \\
3 ;[0 ; 17]\end{array}$ & $\begin{array}{l}5.9(6.4) \\
5 ;[0 ; 22]\end{array}$ & $\begin{array}{c}\text { Men } \\
(\mathrm{n}=15)\end{array}$ & $\begin{array}{l}4.7(6.4) ; \\
3 ;[0 ; 22]\end{array}$ \\
\hline & & $\begin{array}{l}\text { Woman } \\
(\mathrm{n}=20)\end{array}$ & $\begin{array}{c}9.8(7.4) \\
8.5 ;[0 ; 23]\end{array}$ & & $\begin{array}{c}\text { Woman } \\
(\mathrm{n}=20)\end{array}$ & $\begin{array}{l}6.8(6.3) \\
6 ;[0 ; 22]\end{array}$ \\
\hline
\end{tabular}

NDI - Neck Disability Index; ODI - Oswestry Low Back Pain Disability Index 
Table 4 (on next page)

Effects of intensive and moderate levels of physical activity on the nature of pain and frequency of pain episodes in individual groups (NW Chi-square (highest reliability) and Pearson's Chi-square test) 
1

\begin{tabular}{|c|c|c|c|c|}
\hline & \multicolumn{4}{|c|}{ Vigorous physical activity } \\
\hline & \multicolumn{2}{|c|}{ Frequency } & \multicolumn{2}{|c|}{ Time } \\
\hline & NW Chi-square & $\begin{array}{c}\text { Pearson Chi- } \\
\text { square }\end{array}$ & NW Chi-square & $\begin{array}{c}\text { Pearson Chi- } \\
\text { square }\end{array}$ \\
\hline Kinesitherapy & $\mathrm{p}=0.018$ & $\mathrm{p}=0.017$ & $\mathrm{p}=0.080$ & $\mathrm{p}=0.080$ \\
\hline Physical therapy & $\mathrm{p}=0.066$ & $\mathrm{p}=0.067$ & $\mathrm{p}=0.010$ & $\mathrm{p}=0.027$ \\
\hline Massage & $\mathrm{p}=0.433$ & $\mathrm{p}=0.571$ & $\mathrm{p}=0.205$ & $\mathrm{p}=0.414$ \\
\hline \multirow[t]{4}{*}{ All groups } & $\mathrm{p}=0.037$ & $\mathrm{p}=0.029$ & $\mathrm{p}=0.003$ & $\mathrm{p}=0.003$ \\
\hline & \multicolumn{4}{|c|}{ Moderate level of physical activity } \\
\hline & \multicolumn{2}{|c|}{ Frequency } & \multicolumn{2}{|c|}{ Time } \\
\hline & NW Chi-square & $\begin{array}{l}\text { Pearson Chi- } \\
\text { square }\end{array}$ & NW Chi-square & $\begin{array}{c}\text { Pearson Chi- } \\
\text { square }\end{array}$ \\
\hline Kinesitherapy & $\mathrm{p}=0.021$ & $\mathrm{p}=0.011$ & $\mathrm{p}=0.183$ & $\mathrm{p}=0.312$ \\
\hline Physical therapy & $\mathrm{p}=0.206$ & $\mathrm{p}=0.294$ & $\mathrm{p}=0.076$ & $\mathrm{p}=0.105$ \\
\hline Massage & $\mathrm{p}=0.253$ & $\mathrm{p}=0.235$ & $\mathrm{p}=0.275$ & $\mathrm{p}=0.467$ \\
\hline All groups & $\mathrm{p}=0.074$ & $\mathrm{p}=0.176$ & $\mathrm{p}=0.153$ & $\mathrm{p}=0.182$ \\
\hline
\end{tabular}

2 